\title{
Beyond a Constraining Dissensus: The Role of National Parliaments in Domesticating and Normalising the Politicization of European Integration ${ }^{1}$
}

\author{
Sandra Kröger(1) and Richard Bellamy(2)
}

1. Department of Politics, University of Exeter, Amory, Rennes Drive, Exeter, EX4 4RJ, UK. E-mail: $\underline{\text { S.Kroeger@exeter.ac.uk }}$

2. Max Weber Programme, European University Institute, Via dei Roccettini, 9, 50014 San Domenico di Fiesole (FI), Italy e.mail: richard.bellamy@eui.eu

\begin{abstract}
At the heart of the growing politicization of the EU lies a concern with how European integration potentially undermines forms of communal self-government linked to established political identities. This concern originates not from the much discussed democratic deficit of EU institutions but from a 'democratic disconnect' between domestic democratic institutions and processes and the decisions made at the EU level by national executives and EU officials. Our contention is that enhancing the role of national parliaments in EU decision-making offers a way to reconnect the integration process with the communal self-rule of the member states. We ground this argument in an account of the normative basis of the EU that we dub 'republican intergovernmentalism'. We argue that national parliaments offer a means for what we term the domestication and normalization of EU policy-making within the democratic processes of the member states. However, these effects will only occur if mainstream domestic parties employ these new parliamentary powers to develop competing EU policies that reflect their core ideological positions and those of their voters. We propose the introduction of a Parliamentary Legislative Initiative as a mechanism to provide an incentive for them to do so.
\end{abstract}

Keywords: EU, Democratic Deficit, National Parliaments, Political Parties, Republican Intergovernmentalism, Demoi-cracy, Parliamentary Legislative Initiative 


\section{Introduction: The Political Identity Ghost in the European Integration Machine}

The Euro crisis has reinforced the doubts of certain prominent analysts of the EU about whether the course of integration can be addressed adequately in either neofunctionalist or liberal intergovernmental terms (Hooghe and Marks 2009; Scharpf 2015; Vilpisauskas 2013). Both these approaches tend to ignore a development that scholars have dubbed 'politicization' - the increasing awareness, salience, polarization of and mobilization around EU affairs in domestic politics, and the expansion of domestic actors, such as Eurosceptic parties and National Parliaments (NPs), in the EU's decision-making processes (Hutter and Kerscher 2014). This politicization has gone together with the end of the 'permissive consensus' that characterized the pre-Maastricht phase of European integration and a shift towards what Liesbet Hooghe and Gary Marks (2009: 5) have called a 'constraining dissensus', typified by multiple forms of Euroscepticism. We shall argue that the explanatory weaknesses of neo-functionalism and intergovernmentalism associated with the increased politicization of EU affairs call for a fresh look at the role that National Parliaments (NPs) should and could play in the context of EU multi-level governance.

As numerous commentators have noted, the Euro crisis has brought to the fore a tension within the integration process that has been present since Maastricht. Following Hooghe and Marks (2009), the fault line of this tension can be located between the functional and economic factors that promote European integration, on the one hand, and the normative, cultural and social psychological factors associated with political identity and the desire for national self-determination, on the other (Hooghe and Marks 2009: 2). Neo-functionalists hoped that the benefits of economic coordination at the European level would ultimately 'spill over' into an increasing acceptance of the legitimacy as well as the effectiveness of gradually shifting collective decision-making to supranational institutions (Haas 1958; Risse 2006). By contrast, liberal intergovernmentalists contended that so long as the integration process remained under the control of the executives of the member states, then the demands for national democratic legitimacy were satisfied (Moravcsik 2008). If neofunctionalists looked forward to a point where the EU might itself gain both the institutional capacity and the affective allegiance required to resolve the democratic 
deficit of EU level decision-making, liberal intergovernmentalists denied the existence of any such problem in the first place.

These analyses have proved too optimistic. Since the debates around the Maastricht Treaty in the early 1990s, what had previously been described as the 'permissive consensus' has come to an end. 'Permissive consensus' referred to the assumed consent of European electorates with the project of integration, which was driven by elites who operated mainly in camera. As the difficult passage of the Maastricht Treaty, the failure of the Constitutional Treaty and the increasing electoral success of Eurosceptic and right-extreme political parties have made abundantly clear, that elite driven passive consensus no longer suffices. Indeed, the associated shift of legitimate decision-making 'on a range of vital issues ... from an insulated elite to mass politics' (Hooghe and Marks 2009: 13) has sparked a legitimacy crisis. For this change has meant the EU has gone public, yet not all of the public likes what it sees. This trend has become yet more pronounced as the Euro crisis has ensured that EU affairs have not only had a prominent place in national debates (Closa and Maatsch 2014; Miklin 2014; Wendler 2014; de Wilde and Zürn 2012), but also become more contested than had hitherto been the case (Hutter and Grande 2014). Crisis-related decisions, such as those to provide financial support to Greece or on measures like the European Stability Mechanism (ESM) or the Fiscal Compact, have prompted wide debate and media attention, and provoked public protest in many member states. ${ }^{2}$

This politicization of EU affairs has gone hand in hand with declining levels of trust in the EU - especially in those countries worst hit by the crisis (Matthijs 2014). As Eurobarometer polls had long revealed, and the crisis has made ever more marked, identity has not followed function. The EU may have acquired more competences, (de Wilde and Zürn 2012) yet citizens have remained attached not just culturally but also politically to their member states. As a result, the growing politicization of the EU has served not to mobilise greater citizen participation at the EU level, where electoral turnout in European Parliament (EP) elections has steadily declined since 1979, dipping below $50 \%$ in 1999 to fall to an all time low of $42.61 \%$ in 2014 . Rather, the politicization of the EU has manifested itself at the national level, most particularly in electoral defeats for governments deemed to have been too submissive towards contested EU level policies or in the increase of votes for Eurosceptic and anti-system parties. This problem cannot be attributed to a democratic deficit at the EU level alone. The gradual extension of the EP's powers has neither stemmed the process of 
electoral decline in European elections nor reduced the rise of Eurosceptic parties at both the domestic and the EU level. Instead, the politicization of the EU within the member states testifies to a democratic 'disconnect' between domestic democratic processes (Lindseth 2010: 234), within which most citizens remain primarily engaged, and EU decision-making by national executives and political and legal actors at the EU level.

In what follows, we shall argue that NPs can play an important role in overcoming this growing tension between European integration and communal selfrule by reconnecting the one to the other. They can do so by providing a means for what we shall call the domestication and normalization of EU policy-making. The possibility for their so operating arises because the politicization of EU affairs need not be equated with Euroscepticism and the rise of populist movements. Instead, politicization should be regarded and deployed as a positive and necessary feature of democratic politics. A number of reasons motivate this argument. First, without politicization in EU affairs there is a reduction of policy choice. A key feature missing from most domestic EU debates has been the left-right polarization of EU affairs among the non-Eurosceptic parties and the government and the opposition (Puntscher Riekmann and Wydra 2013). As a consequence, substantial policy choice gets reduced. However, when parties fail to offer citizens such choices they deprive them of political efficacy during elections because they cannot select between alternative government programs. Second, and relatedly, this lack of policy choices means that those who disagree with the governmental position go un-represented. Given governments tend to adopt pro-integration positions regardless; a representation deficit gets built into the very system of EU decision-making, prompting the Eurosceptical challenge (Bellamy and Kröger 2013). Third, politicization reduces the scope for blame shifting by politicians as a result of their exploiting the lack of clear lines of responsibility in the EU's multilevel decision-making structure. The more EU affairs get publicly discussed the less it will be possible for governments to participate in EU decision-making, on the one hand, while blaming others for the results of that same decision-making, on the other hand. Finally, the more politicized and public the EU becomes, the more stable it is likely to be as practices of domesticated and normalized opposition overtake populist Euroscepticism as the mainstream form of disagreement and protest. In all these respects, politicization proves desirable not so much for its potential contribution to supranational demos-creation, as for its 
beneficial effects for the democratic reconnection of the executives involved in EU policy-making with their domestic constituencies. As a result, the growing politicization of EU affairs within the member states could be moved beyond a mere constraining dissensus on integration into a means for obtaining the active consensus of the various European peoples in the shaping as well as the control of that process. Our contention, though, is that this result can only be achieved by reinforcing rather than supplanting or constraining communal self-rule and established political identities.

We shall argue that the basis for this approach lies in the multilevel and demoi-cratic normative ordering of the EU itself (Cheneval and Schimmelfennig 2013; Nicolaïdis 2013). On this account, the legitimacy of EU level decisions rests on their satisfying the normative logic of a two-level game (Bellamy and Weale 2015; Putnam 1988, Savage and Weale 2009), whereby they must be acceptable not just to the contracting national executives but also to the respective demoi they claim to represent. From this perspective, negotiators must treat each other with mutual respect as representatives of their citizens; appreciating that the legitimacy of their decisions depends on their retaining the on-going, democratic support of all their different peoples. Such an approach rejects the elitism of not only neo-functionalism but also liberal intergovernmentalism. If the failure of a sufficient transfer of affective political allegiances from the national to the EU level forces the former to continue the dirigisme associated with the Monnet method, the latter has too often reflected the capacity of those business and other groups able to profit from integration to promote their interests with governments without addressing the concerns of those for whom the economic, social and cultural advantages often prove less clear cut. By contrast, we characterise our approach as 'republican intergovernmentalism' (Bellamy 2013), seeing the role of NPs as a way of ensuring that the decisions of governments at the EU level operate under the equal influence and control of their peoples, whilst recognising the obligation of all other member states to operate similarly. The demoicratic logic of this two level game entails that European integration needs to show equal concern and respect for the capacity for communal self-rule of its constituent parts (Bellamy and Weale 2015), supporting and sustaining and where necessary supplementing that capacity rather than substituting for it. Yet, these requirements need not be regarded as constraining any further European integration or even as rolling it back - rather they enable its shaping by the citizens of the European states - 
a point we underline through a proposal for a positive measure, the Parliamentary Legislative Initiative.

The paper unfolds as follows. Section 2 outlines the normative basis for the involvement of NPs in EU decision-making within the EU's demoi-cratic constitutional order, outlining 'republican intergovernmentalism'. Section 3 explores how far NPs currently live up to this role as mechanisms for the domestication and normalization of EU policy-making, noting the picture to be mixed. Although many of the institutional structures for the domesticating of EU policy-making exist, politicians and parties lack the incentives to employ them in a normalising way. Section 4 suggests their performance in this regard might be improved if NPs possessed not only scrutiny powers but the possibility to put forward parliamentary legislative initiatives (PLIs).

\section{Democratic Legitimacy in a Multilevel Europe - Towards a Republican Intergovernmentalism}

Hooghe and Marks have argued that tensions are inherent to the integration process because 'the functional need for human co-operation rarely coincides with the territorial scope of community', so that the demand of communities 'for self rule is almost always inconsistent with the functional demand for regional authority' (Hooghe and Marks 2009: 2; Rodrik 2011). Yet, neo-functionalists could retort that in the long run the change in the locus of communal identification they hypothesise may come about. Of course, as Keynes famously remarked, 'in the long run, we are all dead' (Keynes 1923: 80), rendering the long run 'a 'misleading guide to our current affairs' and its invocation 'too easy, too useless a task' when it comes to meeting the challenges of the present (Keynes 1923: 83). Nonetheless, Hooghe and Marks's thesis might be regarded as resting on a historically contingent set of circumstances. Not only could the conditions that have given rise to this tension pass but also advocates of a federal Europe could argue they should do so, given that such sentiments are most ardently expressed by traditionalists and authoritarians who exploit the temporary plight of the current losers from the integration process. By contrast, we shall suggest that the continued demand for communal self-rule at the national level has both a more justified normative basis and one that is reconcilable with recognising the functional and other demands for greater coordination at the European level. 
Moreover, NPs play a key role in this reconciliation.

The normative basis for this approach lies in what has been termed the demoicratic character of the EU: the contention that the EU involves an ever closer union of peoples rather than the evolving formation of a European people or demos, and exists to serve their joint and several interests (Cheneval and Schimmelfennig 2013; Nicolaïdis 2013). On the version of this thesis adopted here (Bellamy 2013), the political and constitutional systems of the member states should be viewed as offering the democratic means whereby their citizens have been able to agree collectively on their mutual rights and obligations as equal participants within a shared political space. This argument goes back to the defence of the moral standing of states elaborated by Kant (Flikschuk 2010; Stilz 2009). According to this thesis, the integrity of the legal and political structures of each of the member states deserves respect as having elaborated over time their own distinctive civic cultures and instantiated various special obligations and an associated political identity among their respective peoples. However, political communities do not exist in isolation. They interact and develop relations of interdependence. Military threats and outright aggression provide the most obvious negative ways one political community may interfere with or dominate another. But there are also numerous other and subtler forms of mutual influence. For example, international trade may be of very unequal benefit if the superior bargaining power of one or more of the trading partners puts them in a position to impose terms on the others. They can also be harmed by, or benefit from, the negative and positive externalities of each other's domestic policies. When one community has laxer environmental regulations than those of its neighbours, say, its neighbours may suffer from the resulting pollution and the competition of cheaper goods, while it may benefit from the clean air and the less competitively priced goods produced by their superior measures. Political communities may also need or wish to cooperate to control a range of activities that operate across their respective borders, from international finance and the operations of multinational corporations, to transnational terrorism. Such activities include the development of mutually beneficial trade relationships, such as the creation of a single market. The EU offers a response to these various developments and their growing importance in an increasingly globalised and interconnected world. On the demoi-cratic account, though, its purpose is not to supplant the already existing political systems of the member states. Rather, the EU's rationale lies in supporting 
their right to self-government by ensuring these political communities show each other equal concern and respect, and can cooperate effectively and equitably to tackle shared problems. It achieves this result through regulating their mutual interactions and organising their cooperation in ways that avoid domination - not least through forms of supranational governance that treat all contracting member states on equal terms, regardless of population size, military power or wealth, and that remain under their joint and equal control (Pettit 2010).

By contrast to both the neo-functionalist and the liberal intergovernmental approaches, the demoi-cratic approach links the functional argument for European integration to communal self-rule. Unlike neo-functionalists, demoi-crats do not regard the functional case for supranational institutions and regulations as invoking a quasi-federal teleology involving the formation of a European demos and an associated EU level democratic system on the model of the domestic political systems of the member states. Instead, the demoi-cratic approach regards supranational institutions as delegated authorities that are best conceived as agents of the member states (Lindseth 2010: 227). Yet, the normative conditions motivating this view are not satisfied by liberal intergovernmentalism either. A demoi-cratic approach requires that governments act with the active rather than the passive consent of their respective peoples, responding to the commonly avowed interests of all their citizens rather than the particular interests of certain well-organised groups. On this account, agreements between member states at the EU level must follow the normative logic of a two-level game (Putnam 1988; Bellamy and Weale 2015): they must both be equally acceptable to the governments that negotiate them and to the citizens that each of these governments represents. The legitimacy of EU level decisions, therefore, depends on them meeting a dual standard. These decisions must reflect the consent of each of the demoi to whom they apply and they must not undermine the capacity for those demoi to give or withdraw that consent. As such, this approach operates as a form of 'republican intergovernmentalism' (Bellamy 2013), since it requires the on-going democratic authorisation and accountability of governments by and to their citizens, albeit indirectly via their elected representatives, in EU decision-making. Our claim is that the growing 'constraining dissensus' results from the integration process having increasingly failed to meet these criteria, as the so-called 'executive federalism' (Habermas 2012) that has characterised the management of the Euro crisis illustrates. Yet, there are also encouraging moves to alter the institutional structures of EU 
decision-making so as to better satisfy these conditions and so meet the challenge of growing domestic dissent, not least through the new powers allotted to NPs.

The most consistent and prominent articulation of such demoi-cratic normative reasoning has come from the German Federal Constitutional Court. In a series of judgments going back to 1974, the Court has insisted that while there are important functional reasons for European integration the resulting arrangements and policies cannot be such as would be incompatible with or undermine the right to communal self-government embodied in the Basic Law of the German Constitution. Increasingly, such arguments have been voiced more widely with the result that they found expression post-Lisbon in Article 4.2 of the Treaty on European Union (TEU), which specifies that 'The Union shall respect the equality of Member States before the Treaties as well as their national identities, inherent in their fundamental structures, political and constitutional, inclusive of regional and local selfgovernment.' In a similar vein, the revised Article 5.2 TEU now insists on 'the principle of conferral', emphasizing that 'the Union shall act only within the limits of the competences conferred upon it by the Member States in the Treaties to attain the objectives set out therein.' As the German Federal Constitutional Court noted in its Lisbon judgement (2009), this principle upholds the member states as 'the primary political area of their respective polities', with the EU only having 'secondary responsibility for the tasks conferred on it.'

It is no coincidence, therefore, that Lisbon also witnessed a new emphasis on the role of NPs, with Articles 10 and 12 of the TEU recognizing them for the first time in the main body of the Treaty as forming an integral part of the EU decisionmaking process. As Peter Lindseth (2010: 24, 234-35) has noted, from the demoicratic perspective, as outlined above, the democratic legitimacy of the EU suffers less from a democratic deficit within the EU's supranational institutions and more from a democratic disconnect between EU level policy-making and the democratic processes of authorization and accountability at the member state level. The past side-lining of NPs by executives and EU institutions, to the extent that they were designated as the 'losers' of the integration process (Maurer and Wessels 2001), has played an important part in this disconnect. Consequently, their revitalization within EU affairs offers a means of democratic reconnection. Once again, the German Federal Constitutional Court has pursued this line of reasoning assiduously by noting how the self-determination of the German demos was intimately linked to its Parliament, in 
this case the Bundestag, retaining meaningful influence over German involvement in EU policies, including economic policy post-EMU (Federal Constitutional Court 2014a). As the Court noted in its decision on the ratification of the Treaty Establishing the European Stability Mechanism, the Bundestag cannot abrogate its responsibility to decide its own budget nor can the German government undertake an open-ended liability for another state's debts (Federal Constitutional Court 2014b). According to the Court, NPs provide the main mechanism through which a people are represented and can influence policy-making, albeit indirectly through national elections. They serve as the arena within which a people can collectively shape its 'economic, cultural and social living conditions' according to their civic traditions and values. In the Court's view, NPs cannot abrogate that function - indeed, they have a duty to defend it (Federal Constitutional Court 2009).

Two roles emerge for NPs from this analysis. On the one hand, as acknowledged in part in their function as guardians of subsidiarity, NPs have a duty to ensure the EU only undertakes measures that lie within the competences member states have conferred upon it and that could not be achieved as effectively by action at the member state level. On the other hand, they need to ensure that the EU policies agreed and promoted by national governments and carried forward by various supranational actors respond to the democratic will of the various demoi and are capable of retaining their on-going support.

In developing these two roles, NPs can close the democratic disconnect by domesticating and normalising EU policy-making. They domesticate it by taming it and bringing it home. It can be tamed by NPs not only using their subsidiarity checking powers, such as the Early Warning Mechanism (EWM), but also exercising more control over government ministers via EU Affairs and other Committees to ensure EU policies do not unduly encroach on or subvert what the German Constitution Court designates 'essential areas' of domestic 'democratic formative action ', such as 'citizenship, the civil and the military monopoly on the use of force, revenue and expenditure including external financing and all elements of encroachment that are decisive for the realisation of fundamental rights' (Federal Constitutional Court 2009). In making use of these instruments they can also bring EU policy-making home and thereby normalize it so that debates about more or less integration get related to the normal domestic debates concerning the character and quality of particular policies in terms of the broader ideological commitments of 
citizens, particularly their position on the left-right spectrum.

On this account, European integration need neither come at the cost of a loss of communal self-rule nor be regarded as in 'inevitable' tension with it, so that the assertion of one always comes at the expense of the other. Rather, when viewed from a republican intergovernmentalist perspective as a derived fundamental order, the EU can be conceived as needing to be democratically connected to, and dependent for its legitimacy upon, the legal and political systems of the member states. Within this framework, the politicization of EU affairs can be shifted away from Euroscepticism, undeniable though this phenomenon has been hitherto. Through being domesticated and normalized by the structures and processes of party competition within NPs, politicization can serve to reconnect the different levels of governance in the EU both to each other and to the citizens of the various demoi, thereby improving the quality of representation in the mid and long term. By stemming from, rather than operating against, communal self-rule, politicisation can go beyond the constraining dissensus. For by being channelled within, rather than having to go outside, normal domestic channels, such politicization can allow a form of European integration to emerge that is capable of obtaining the on-going assent of the citizens of Europe's various demoi.

\section{The Role of NPs in Domesticating and Normalizing EU Policy-Making}

This section assesses the degree to which the domestication and normalization of EU policy-making, as defined in the previous section, have occurred in NPs, with the subsequent section drawing on this assessment to present a constructive proposal for improvement. The analysis differentiates between the institutional structures NPs have developed to domesticate the EU, on the one hand, and the usage of those structures by individual members of parliament (MPs) and political parties in ways that normalize debates on the EU, on the other. Given parliamentary politics is ultimately party politics, particular attention needs to be given to evaluating how far these domestic institutional structures provide adequate incentives for the main political parties to debate EU policies in ways their reflect their normal ideological commitments and divisions. As we shall see, at present the incentives provided to parties by existing structures are mixed, with the result that NPs currently operate as imperfect channels of domestication and normalization. 


\section{Domestication}

NPs were long considered the 'losers of integration' (Maurer and Wessels 2001). Their role was not formally recognised within the EU Treaties, while the integration process allowed executives to circumvent their oversight in a growing number of policy areas. Proposals for improving the democratic credentials of the EU focussed on the steady enhancement of the powers of the EP (Rittberger 2005), thereby marginalising NPs yet further. Despite these difficulties, NPs have gradually learnt to 'fight back' and parliamentary attention to EU affairs has clearly increased over the past two decades. NPs have implemented institutional reforms in reaction to the increased importance of the EU (Karlas 2012; Winzen 2012), and the EU has given them more competences in turn. As a result, NPs have developed the institutional capacity to domesticate EU policy-making, at least to some extent.

The potential to tame and bring the EU home has been aided by NPs setting up European Affairs Committees (EACs), though important national differences remain as to how powerful these are (Karlas 2012; Winzen 2013). Institutional reforms have been particularly pronounced in member states where both parliamentary authority and Euroscepticism are strong (Raunio 2005; Winzen et al. 2014). Particularly following the Lisbon Treaty all NPs have benefitted from improved information and new powers that allow them to scrutinise their own executives more effectively, enter into dialogue with the European Commission, exercise a subsidiarity check and cooperate with other NPs and with the EP to inform and control EU level decisionmaking.

According to the new 'Protocol on the Role of National Parliaments', NPs now receive a wide range of documents, including Commission consultation documents and draft legislative acts, directly rather than via their governments, as under the Treaty of Amsterdam.

They also have acquired enhanced scrutiny powers with regard to executive action in the EU, with many NPs adopting either the documentary or especially the mandating models of oversight developed by the UK and Danish Parliaments respectively from the 1970s onwards (Lindseth 2010: 200-225). Parliaments differ over whether they scrutinise EU documents or the government's position for negotiations in the Council or both, and whether they offer a written statement or 
transmit their position to governments orally, in committee. The documentary model involves a 'scrutiny reserve', whereby the government cannot undertake action at the supranational level until parliamentary scrutiny of the relevant proposal is complete. The reserve can only be overridden by Ministers offering 'special reasons' for doing so, this reason giving requirement being further reinforced by the need under the UK model for governments to provide an explanatory memorandum on every European document. The Danish mandating model has been seen as even more demanding, with the government being required to consult on all decisions of major importance and present their negotiating position for approval by the parliamentary committee. Both models potentially improve the ability of legislators to understand EU proposals, on the one hand, while making the positions of national executives more transparent, on the other.

EACs and parliamentary scrutiny more generally not only support the domestic communication and debate of EU policy-making but also foster a capacity to tame it by promoting respect for communal self-rule. That occurs both by insisting on the need for domestic democratic authorization for EU measures and by ensuring the process of European integration respects the primacy of the domestic democratic sphere through being limited to those measures that can be most effectively and efficiently achieved at the supranational level. This latter element lies behind the growing assertion of the subsidiarity principle from the Treaty of Maastricht onwards, culminating in the introduction of the EWM in the Lisbon Treaty, which permits NPs to police subsidiarity and proportionality by way of the so-called yellow and orange cards (Protocol on the Application of the Principles of Subsidiarity and Proportionality, Article 7). The issuing of 'reasoned opinions' by NPs also allows them to enter into political dialogue with the Commission. Following the so-called 'Barroso Initiative', the Commission undertook to reply to all contributions sent to it by NPs, even those that did not relate to subsidiarity (Jančić 2012). Additionally, NPs can challenge legislative acts on grounds of their infringing subsidiarity by bringing an action before the Court of Justice. Moreover, they are now involved in the evaluation of measures taken within the area of freedom, security and justice (Articles $70,85,88$ ), while an individual NP may block Treaty changes under the simplified revision procedures by vetoing the so-called passerelle clause, (Article 48). They must also be informed of new applications to join the EU (Article 49). 
Finally, NPs engage in inter-parliamentary cooperation. Because the EWM requires coordination among the $28 \mathrm{NPs}$, it promotes inter-parliamentary networking and the exchange of information (Cooper 2013; Sprungk 2013). COSAC (the French acronym for the 'Conference of Community and European Affairs Committees of Parliaments of the European Union') is the most developed form of interparliamentary cooperation. It is officially authorized 'to submit any contribution' that it deems appropriate to the EP, the Council and the Commission. Inter-parliamentary bodies have also developed in those areas where EU institutions and actors operate at the borders of their sphere of competences and possess a degree of executive discretion: namely, Financial and Monetary Policy and Common Security and Defence Policy (see the contribution by Cooper in this issue). Such bodies provide mechanisms for NPs to retain their power to scrutinize executive action in areas where national governments have delegated their authority to EU officials.

In sum, we can see that although the competences of NPs - and governments have been reduced in the context of European integration, they have begun to acquire the institutional capacities and legal capabilities to control not only their conferral to the EU level but also to monitor and influence their use. As a result, the structures exist for domesticating EU policies along the lines of the republican intergovernmental model outlined in the last section. However, these mechanisms will only operate as a means for democratically reconnecting the EU to the demoi of the member states to the extent they are employed by national political parties and form part of the normal processes of political contestation. Otherwise, the politicization of EU affairs at the domestic level will remain the terrain of Eurosceptical parties protesting against an on-going democratic disconnect.

\section{Normalization}

As we noted, politicization involves the greater salience, polarization of and mobilization around EU affairs. By the normalization of this phenomenon we mean the debate of alternative EU policies by the non-Eurosceptic political parties, according to their characteristic ideological commitments. Such normalized ideological debates would turn less on the legitimacy of the EU or its actions per se, matters that preoccupy the Eurosceptic parties, and more on reasonable disagreements concerning the particular policies that the EU puts forward or implements. In this 
way, party competition over EU policy could become attuned to the core domestic policy concerns and divisions of voters.

Hitherto the EU institutional space has done anything but encourage the active engagement of domestic political parties in EU affairs. The legal and political structures of the EU have progressively decreased the domestic political alternatives available to national parties in a number of ways (Bellamy and Kröger 2014). They have been restricted a) by way of the transfer of competences to the EU, which limits the available 'policy space' in which parties can intervene (Mair 2007); and b) by the prioritizing of the completion and realization of the internal market over other political aims, which reduces the 'policy repertoire' available to parties and thereby the opportunities for them to disagree and propose alternatives (Mair 2007). These restrictions impact on the degree of political contestation and debate between parties by constraining in their turn the area of reasonable disagreement between them: a) by way of the supremacy and direct effect of EU law as interpreted and upheld by the Court of Justice and its claims to 'competence-competence' in deciding whether it may legitimately override national constitutional objections or not; and b) by way of the party political composition of the main EU institutions (an institutionalized 'grand coalition') and the consensus-oriented nature of the EU's institutional setting more generally, which produces legislative proposals that reflect a somewhat centrist compromise that tries ex ante to anticipate and integrate the interests and concerns of both centre-left and centre-right parties, rendering political conflict about the proposals difficult once they come before NPs. As a result, parliamentary attempts to contest or debate the integration process risk becoming unreasonable. NPs have had no choice but to adapt to and implement EU law. The net effect of these factors is a reduction in political alternatives that national governments - and thereby parliaments and parties - can offer to voters, which in turn decreases electoral competition, rendering elections less decisive (see also Nanou 2013). In turn, parties attempt to avoid the politicization of EU policies, given that under these conditions it is hardly an attractive electoral issue.

The new parliamentary procedures described above can potentially help overcome these constraints by providing domestic democratic channels through which EU policies can be pursued. The crux is whether parties have adequate incentives to employ them. For parties to politicize an issue in the manner described above, four conditions must usually be met (Miklin 2014). First, the issue must be sufficiently 
salient to affect the choices of the party's voters. Second, the party's position on the issue needs to be congruent with that of its voters. Third, its position needs to be sufficiently internally cohesive to avoid internal conflicts. Finally, the party's competitors need to hold different positions that allow for polarization. Hitherto, these conditions have only applied to Eurosceptic parties with regard to EU affairs. However, the Euro crisis has undoubtedly raised the awareness of national electorates about the impact of EU policies on their lives. As such, it offers a good test case of the degree to which adequate incentives exist for other political parties to use the new domestic institutional structures to normalize the politicization of the EU. Although the published empirical evidence is still sketchy, it nonetheless allows us to offer a preliminary assessment with regard to each of the four conditions.

First, the salience of EU affairs in domestic debates and elections, and even in EP elections, has traditionally been low (Reif and Schmitt 1980). However, crisisrelated decisions, such as those to provide financial support to Greece or measures like the European stability mechanism or the Fiscal Compact, have generated parliamentary debate (Wendler 2014; Puntscher Riekmann and Wydra 2013; Closa and Maatsch 2014, and the contribution by Wonka and Göbel in this issue) and media attention throughout the Euro-zone, and resulted in public protest in many member states. Also, more governments than ever before in the history of the EU have been voted out of office, many clearly as a result of the austerity measures they had felt obliged to implement because of their undertakings as members of the Euro-zone. Therefore, the salience criterion has been met.

Second, many non-Eurosceptic parties, particularly the major parties, have traditionally held more positive views towards the EU than their voters (Hooghe and Marks 2008). This lack of congruence has disinclined them from politicizing EU affairs. This gap appears to have widened with the crisis, both in debtor and in lender states, with national electorates objecting to the financial cuts or spending respectively to which their governments have agreed. By contrast, smaller parties at the extremes of the political spectrum, particularly those on the extreme-right, tend to enjoy a greater congruence with their voters on EU affairs and have been able to exploit the crisis to promote their Eurosceptical views (Green-Petersen 2012; Mattila and Raunio 2012).

Third, many parties lack cohesion through being internally divided over the EU. Whilst broadly sympathetic to the idea of European integration, social democrats 
can worry about the implications of the internal market and of neo-liberal policies stemming from the EU. They often see the domestic welfare state as endangered. By contrast, conservative parties often divide along traditionalist lines, as in the UK, with some members seeing the EU as a source of excessively liberal policies in areas such as free movement or anti-discrimination regulations (see Auel and Raunio 2014). We are aware of no literature as yet on whether the internal coherence of mainstream parties on EU policies has increased or decreased since the outbreak of the crisis.

Finally, the fourth condition of polarization is the most important for democratic reconnection by parties. For the reasons explored above, mainstream parties have hitherto agreed more than they have disagreed about EU policies, particularly in such European integration-friendly member states as Germany (see Auel and Raunio 2014; and Wonka and Göbel in this issue). As a result, public disagreement has focused on the constitutional question of whether there should be more or less Europe rather than on what kind of policies the EU should pursue. Given their own internal divisions and their lack of congruence with their voters, in this context the main parties could hardly hope to gain votes by highlighting EU issues.

Has this absence of domestic party competition around the EU changed with the Euro crisis? To some degree, it seems so. NPs have debated the Euro crisis, and ideological conflicts between the left and the right have come to the fore (Baglioni and Hurrelmann 2014; Closa and Maatsch 2014; Hutter and Kerscher 2014; Maatsch 2014; Puntscher Riekmann and Wydra 2013; Wendler 2012; and Raunio, and Wonka and Göbel in this issue). Indeed, Frank Wendler contends that the plenary debates in the British, French and German parliaments on the Euro crisis generally adjust to the established logic of party politics at the domestic level (Wendler 2014a). However, it also seems that these ideological divides have often been side-lined by the main parties feeling obliged to act 'responsibly' and simply approve rescue measures (Mair 2011; Puntscher Riekmann and Wydra 2013).

Adapting Wendler's (2014b: 5-6) categorisation of the framing arguments used in parliamentary discourse on the crisis, we can distinguish disagreements of an ideological kind regarding the character and advisability of a given policy, such as we have associated with a normalized politicization of the EU, from disputes of a pragmatic kind concerning the technical efficacy of EU action, and anti-systemic objections questioning the very legitimacy and justice of the EU, typical of Eurosceptic parties. The evidence Wendler presents suggests that the main parties 
favoured a pragmatic discussion of austerity measures over a debate that reflected their normal ideological divisions. As a result, more radical parties of left and right have been able to mount anti-systemic challenges to these measures on grounds of their democratic legitimacy and justice. Similarly, Carlos Closa and Aleksandra Maatsch (2014) note this pattern in their study of parliamentary debates of the European Financial Stability Facility (EFSF) in eleven Euro states. They show party positions were mainly polarized between mainstream parties, be they in government or opposition, that adopted pragmatic arguments favouring rescue measures on functional economic grounds, on the one hand, and more extreme right and left wing parties that employed arguments of an anti-systemic nature, on the other, with rightwing Eurosceptic parties appealing to national values and interests, and the left-wing parties criticizing austerity measures for a lack of solidarity and social justice typical of what they view as the neo-liberal structures of the EU (Closa and Maatsch 2014: 13, 14). A similar assessment emerges from Puntscher Riekmann and Wydra's (2013) study of parliamentary discussion of legislation relating to the Euro crisis between 2010 and 2012 in Italy, Germany, and Austria. The empirical evidence presented shows that legislation relating to the handling of the Euro crisis was passed in NPs by majorities that time and again comprised both government and opposition parties. They also show how the main parties have sought to marginalize criticism of the proposed measures as unrealistic and irresponsible. This suggests opposed positions that might represent the interests of those citizens who could be damaged by particular policies get damned as somehow against the national interest. In consequence, contestation has been left to the largely Eurosceptic parties at the extremes.

Overall, the tendency of major parties to play down the EU varies between member states as mediating factors intervene, such as the national narrative about the EU and media receptiveness to EU issues (de Wilde and Zürn 2012). In fact, EU issues have been most debated in NPs where consensus is greatest rather than where it is weakest (Auel and Tapio 2014). Germany in particular fits this pattern (see the contribution by Wonka and Goebel in this issue). Not only are Eurosceptic parties not represented in Parliament but also the responsibility to take a 'European' decision was in the German case not a matter of passively accepting a decision made by others but, thanks both to its role as the main 'lender' state and to the Federal Constitutional Court's judgment, a decision the Bundestag could potentially shape via its influence 
on the German government. As a result, its debates were perhaps the most ideologically contested of all (Wendler 2014b). Nevertheless, the evidence suggests that even though the powers of NPs have increased with the Lisbon Treaty, the incentives for most parties to deploy them in ways that normalize the politicization of the EU remain weak.

At this stage, not much can be said about normalization via the interparliamentary mechanisms that COSAC, the EWM and other bodies provide, given their recent introduction. However, the prospect for normalization in these contexts seems bleak for several reasons. First, many of their activities are carried out by parliamentary bureaucrats (Högenauer and Neuhold 2014), making them an unlikely candidate for the normalization of EU affairs through political parties. Second, the fusion of the executive and the legislative in most NPs, which implies that it is the government that provides opinions on EU affairs, will not incentivize all parties and MPs to get engaged with these inter-parliamentary mechanisms and bodies. Third, the policing of subsidiarity under EWM involves both a high threshold and is framed in legalistic terms which will hardly inspire mass public debates. It is also concerned more with the constraining of European integration on 'technical' grounds than shaping the kind of policies the EU should have on the basis of particular ideological views. Finally, the EWM does not allow NPs or parties to criticize inaction by the EU or to promote new areas of integration, but is limited to subsidiarity and proportionality checks of legislative proposals.

In sum, the four conditions supporting the normalizing of the domestic debate of EU affairs by non-Eurosceptic parties have only arisen under fairly favourable circumstances, and even then, remain weak. In addition to the first condition of the salience of the EU with the electorate, which is now generally present, two further factors appear particularly important. They relate to the second and fourth conditions of congruence with supporters and the possibility of party polarization. First, parties must not fear giving electoral advantage to smaller Eurosceptic parties on either their left or right. Second, they must feel capable of influencing policy in ways that reflect their distinctive ideological convictions, rather than simply accepting its pragmatic utility or questioning its legitimacy. To a degree the two are mutually supporting. Only if the EU policies advocated by the main parties can be aligned with their core ideological positions will their policies on the EU be likely to be congruent with those of their supporters and so be capable of being the subject of normal party competition 
around polarized policy programmes. The next section offers a proposal aimed at promoting the required congruence and polarization by addressing these two factors.

\section{A Parliamentary Legislative Initiative}

As we have seen, the Euro crisis provides a propitious context for politicization to occur. Indeed, it has prompted debates that have involved a discursive coupling of the EU and the domestic levels, even though the management of the crisis was clearly dominated by the European Council (Dinan 2011: 119). However, it is quite possible that once the Euro crisis is settled political parties and NPs will go back to 'business as usual', preferring not to debate EU affairs. To avoid that happening, and to ensure NPs live up to their role in republican intergovernmentalism of reconnecting the integration process to domestic democratic politics, we believe they need to move out of the shadow of the legacies of both the 'permissive consensus' and the 'constraining dissensus'. We propose that one way to achieve the more permanent coupling of the EU and domestic levels through NPs is through a Parliamentary Legislative Initiative (PLI), as a means of fostering the normalized politicization of the EU by nonEurosceptic parties, which we shall outline below.

Eric Miklin has argued that polarized legislative proposals can help 'to overcome parliaments' reluctance publicly to discuss and compete on EU issues because such proposals change the incentive structure of those large centrist parties that are able to enforce parliamentary debates' (Miklin 2014: 88). However, Miklin discusses the possibility of "top-down politicization through polarising Commission proposals' (ibid.). We consider that such polarized proposals are unlikely to come from the Commission, given the grand-coalition-character of politics at the EU level. But more fundamentally, we argue in favour of bottom-up politicization through greater involvement of NPs, which is more likely to satisfy requirements of communal self-rule and identification with policies.

By a PLI we mean the possibility for NPs to put forward legislative proposals in regard to issues that are of shared concern with the citizens of the demoi of other member states. Such legislative proposals could be either for the EU to initiate legislation in a new policy area, or they could propose the EU modifying or withdrawing from a given policy area. A similar mechanism, the so-called 'green card', has been suggested recently by both the European Committee of the British 
House of Lords and the Dutch Parliament, and is now the subject of a consultation exercise by COSAC. ${ }^{1}$

Similar to the rules of the EWM, we propose that the PLI involve cooperation between NPs. A PLI would be triggered by at least a 1/3 of the MPs in a minimum of a 1/4 of all the NPs in the EU. The total number of NPs would be calculated by counting each chamber in bicameral systems as 1 and weighting the NPs of unicameral systems as 2 . In the case of the threshold being reached, the Commission would be obliged to put forward a legislative proposal to be considered by the normal legislative procedure. As we note below, we set this threshold deliberately below requiring a majority of MPs in 50\% of all NPs in order to stimulate debate in part by empowering opposition parties as much as those in government. The demoi-cratic legitimacy of any measure would still be guaranteed by the normal legislative process requiring a super majority in the Council and the EP for any proposal to be enacted.

How would a PLI work in favour of the four conditions of salience, congruence between parties and voters, internal cohesion and polarization so as to provide a positive incentive structure for political parties to normalize the domestic political contestation of EU affairs? We consider that it will be very unlikely that EU policies will return to the shadow of the permissive consensus (de Wilde and Zürn 2012), given that the Euro crisis measures mean they now impact directly on areas that are electorally salient for most citizens and given the high degree of politicization these policies have already attracted. We also consider that it is next to impossible for parties to not be internally divided - to a greater or lesser degree - over any given policy, and particularly over EU policy. We do not address these two conditions, therefore. Rather, as we noted above, we focus on the impact of the PLI in favouring the two key factors we identified as favouring the crucial conditions of congruence and polarization, which as we saw are linked.

We contend that the PLI should support the two factors lying behind both these conditions. These factors involved i) mainstream parties considering that the politicization of the EU does not advantage Eurosceptic parties, and ii) allows them to adopt positions that reflected their core ideological commitments. Being entitled to

\footnotetext{
${ }^{1}$ HoL EU Committee, $9^{\text {th }}$ Report Session 2013-14, The Role of National Parliaments in the EU, 24 March 2014, pp. 19-20; Questionnaire for the $23^{\text {rd }} \mathrm{Bi}$-annual Report of COSAC, 23 February 2015, Section 2.
} 
influence EU affairs positively rather than merely in a reactive way, through subsidiarity checks, favours both factors. Parties need not be reduced to debating mere technical and pragmatic considerations of a 'responsible' rather than a 'responsive' character, or be forced into opposing the demands for less integration on the anti-systemic grounds deployed by the Eurosceptic parties. Instead, they may seize the initiative to promote a policy measure which accords with their general ideology. Parties in government can push their executives towards adopting proposals that go beyond the compromises they may feel obliged to make as members of an EU level 'grand coalition'. Such moves could aid their bargaining power by revealing a ground swell of domestic support for particular measures. More importantly, the comparatively low threshold of a 1/3 of MPs is designed to allow opposition parties also to promote such initiatives and thereby to put forward alternative EU policies to the government. That not only empowers the opposition to develop EU policies of their own but provides an additional incentive for government parties to also defend their position on ideological grounds. Meanwhile, the need to cooperate with other NPs under the PLI will work against parties acting purely opportunistically or operating in the manner of Eurosceptic parties to protect a narrowly conceived national self-interest.

We observed in the last section how the ability of parties to promote policies that align closer to their ideological identities supports both congruence with their supporters and polarization between parties. To the extent the PLI fosters these developments by non-Eurosceptic parties, therefore, it will allow them to reconnect their input into EU policy-making with the domestic democratic process. In line with republican intergovernmentalism, they will not be tied to merely passively supporting commitments made by their executives at the EU level. Instead, they may shape those commitments and engage directly in dialogue with other NPs as well as EU level institutions. In so doing, they can also move the politicization of EU policy-making away from a constraining dissensus monopolised by Eurosceptic parties that challenge the legitimacy of the EU and towards a more active consensus on the kind of integration the citizens of the different peoples of the EU wish to see. By virtue of these proposals coming from different NPs, the likelihood is that they will support rather than subvert communal self-rule. In other words, they will either be in areas that add value to what member states could manage on their own, or be in areas that strengthen the capacity for self-rule by reducing the potential for decisions in one 
state to create negative externalities that undermine the effectiveness of decisions by others.

\section{Conclusion}

We have disputed the thesis that the politicization of EU affairs needs to be linked to an inexorable tension between European integration and communal self-rule. Instead, re-connecting the integration process to the domestic processes of normal party competition can bridge that tension. We have argued that this approach has a normative basis in a demoi-cratic understanding of the EU that we have called republican intergovernmentalism. In this approach, NPs play a crucial function as mechanisms for what we termed the domestication and normalization of EU affairs. EU policies can be domesticated by being brought home and discussed in domestic forums and tamed so that they do not undermine the domestic democratic processes. However, the incentive structure for non-Eurosceptic parties to use these mechanisms in ways that lead to the normalization of the politicization of EU affairs along the normal ideological divisions that structure most domestic politics is currently largely lacking. In particular, the main government or opposition parties tend to acquiesce to almost all EU measures on pragmatic grounds, or raise mainly technical objections, thereby lending credence to the attempts by Eurosceptic parties to dispute their legitimacy. To counter this tendency, we propose the creation of a Parliamentary Legislative Initiative (PLI) as a way of fostering such normalized debates of EU affairs. We believe it promotes the two factors we identified as likely to support both polarization between mainstream parties and convergence with their electorate by stimulating them to compete on rival EU policies that reflect their core ideological commitments. It does so by encouraging the non-Eurosceptic parties, especially those in opposition, to promote a distinctive package of EU policies without fearing they would merely advantage Euro sceptic parties and that reflect their core ideological perspectives and so are more congruent with their voters and liable to promote normal party polarization through being distinct from those of the government. As a result, EU integration could be reconnected in a positive way to domestic democratic processes.

\section{References}


Armingeon, K. and Baccaro, C. (2012) 'Political Economy of the Sovereign Debt

Crisis: The Limits of Internal Devaluation', Industrial Law Journal, 41:3, 254-275.

Auel, K. and Raunio, T. (2014) 'Debating the State of the Union? Comparing Parliamentary Debates on EU Issues in Finland, France, Germany and the United Kingdom', Journal of Legislative Studies, 20:1, 13-28.

Bartolini, S. (2005) Restructuring Europe. Centre Formation, System Building and Political Structuring between the Nation-State and the European Union (Oxford: Oxford University Press).

Bellamy, R. (2013) 'An Ever Closer Union of Peoples: Republican Intergovernmentalism, Demoi-cracy and Representation in the EU', Journal of European Integration, 35:5, 499-516.

Bellamy, R. and Kröger, S. (2014) 'Domesticating the Democratic Deficit? The Role of National Parliaments and Parties in the EU's System of Governance', Parliamentary Affairs, 67:2, 437-457.

Bellamy, R. and Weale, A. (2015) 'Political Legitimacy and European Monetary Union: Contracts, Constitutionalism and the Normative Logic of Two-Level Games', Journal of European Public Policy, 22.2: 257-74

Braun and Tausendpfund 2014

Cheneval, F., and Schimmelfennig, F. (2013) 'The case for demoicracy in the European Union', Journal of Common Market Studies 51:2, 334-50.

Christiano, T. (1996) The Rule of the Many: Fundamental Issues in Democratic Theory (Boulder: Westview Press).

Closa, C. and Maatsch, A. (2014) 'In a Spirit of Solidarity? Justifying the European Financial Stability Facility (EFSF) in National Parliamentary Debates', Journal of Common Market Studies, 52:4, 826-842.

Dinan, D. (2011) Governance and Institutions: Implementing the Lisbon Treaty in the Shadow of the Euro Crisis, Journal of Common Market Studies, The JCMS Annual Review of the European Union in 2010, 49:s1, 103-121.

Fasone, C. (2012) 'Interparliamentary Cooperation and Democratic Representation in the European Union'. In: Kröger, S. and Friedrich, D. (eds.) The Challenge of Democratic Representation in the European Union (Basingstoke: Macmillan), 41-58.

Federal Constitutional Court (2009) Lisbon Judgement BVerfG, 2 BvE 2/08.

Federal Constitutional Court (2014a), Outright Monetary Transactions, available as: 2 BvR 2728/13 vom 14.01.2014, Absatz-Nr (1-105), https://www.bundesverfassungsgericht.de/entscheidungen/rs20140114_2bvr272813.ht $\underline{\text { ml. }}$ (Accessed 15 August 2014) 
Federal Constitutional Court (2014b), European Stability Mechanism, available as: 2 BvR 1390/12 vom 18.3.2014, Absatz-Nr. (1-245), https://www.bundesverfassungsgericht.de/entscheidungen/rs20140318_2bvr139012.ht ml. (Accessed 15 August 2014)

Follesdal, A. (2014) 'A Common European Identity for European Citizenship?' German Law Journal, 15:5, 765-775.

Flikschuh, K. (2010) 'Kant's Sovereignty Dilemma: A Contemporary Analysis', Journal of Political Philosophy, 18.4, 469-93

Green-Pedersen, C. (2012) 'A Giant Fast Asleep? Party Incentives and the Politicisation of European Integration', Political Studies 60, 115-130.

Habermas, J. (2012) The Crisis of the European Union: A Response, trans. Ciaran Cronin (Cambridge: Polity Press).

Hass, E. (1958) The Uniting of Europe (Palo Alto, Calif.: Stanford University Press).

Hobolt and Wratil 2015

Hooghe, L. and Marks, G. (2009) 'A postfunctionalist theory of European integration: from permissive Consensus to constraining dissensus', British Journal of Political Science, 39:1, 1-23.

Hurrelmann, A., Gora, A. and Wagner, A. (2013) 'The Politicization of European Integration: More than an Elite Affair?' Political Studies, doi: 10.1111/14679248.12090.

Hutter, S. and Grande, E. (2014) 'Politicizing Europe in the National Electoral Arena: A Comparative Analysis of Five West European Countries, 1970-2010', Journal of Common Market Studies, 52:5, 1002-1018.

Hutter, S. and Kerscher, A. (2014) 'Politicizing Europe in Hard Times: Conflicts over Europe in France in a Long-Term Perspective 1974-2012', Journal of European Integration, 36:3, 267-282.

Jančić, D. (2012) 'The Barroso Initiative: Window Dressing or Democracy Boost?', Utrecht Law Review, 8.1, 78-91.

Karlas, J. (2012) 'National Parliamentary Control of EU Affairs: Institutional Design after Enlargement', West European Politics, 35:5, 1095-1113.

Keynes, J. M. (1923) A Tract on Monetary Reform (London: MacMillan).

Lindseth, P. (2010) Power and Legitimacy: Reconciling Europe and the Nation State (Oxford: Oxford University Press). 
Maatsch, A. (2014) 'Are we all austerians now? An analysis of national parliamentary parties' positioning on anti-crisis measures in the eurozone', Journal of European Public Policy, 21:1, 96-115.

Mair, P. (2007) 'Political Parties and Party Systems'. In: Graziano, P. and Vink, M.P. (eds.) Europeanization: New Research Agendas (Basingstoke: Palgrave Macmillan), 154-166.

Mair, P. (2011) 'Smaghi vs. the Parties: Representative Government and Institutional Constraints', Paper prepared for the Conference on Democracy in Straightjackets: Politics in an Age of Permanent Austerity, Ringberg Castle, Munich, 23-26 March 2011.

Matthijs, M. (2014) 'Mediterranean Blues: The Crisis in Southern Europe', Journal of Democracy, 25:1, 101-115.

Mattila, M. and Raunio, T. (2012) 'Drifting further apart: National Parties and their Electorates on the EU Dimension', West European Politics, 35:3, 589-606.

Maurer, A. and Wessels, W. (eds.) (2001) National Parliaments on their Ways to Europe: Losers or Latecomers? Baden-Baden, Nomos.

Miklin, E. (2014) 'EU Politicisation and National Parliaments: Visibility of Choices and Better Aligned Ministers?', The Journal of Legislative Studies, 20:1, 78-92.

Moravcsik, A. (2008) 'The Myth of Europe's "Democratic Deficit"', Intereconomics, 331-340.

Nanou, K. (2013) 'Different Origins, Same Proposals? The Impact of the EU on the Policy Direction of Party Families', West European Politics, 36:1, 248-269.

Nicolaidis, K. (2013) 'European demoicracy and its crisis', Journal of Common Market Studies 51:2, 351-69.

Pettit, P. (2010). 'Legitimate International Institutions: A Neo-republican Perspective'. In: Besson, S. and Tasioulis, J. (eds.) The Philosophy of International Law, (Oxford: Oxford University Press), 139-60.

Putnam, R.D. (1988) 'Diplomacy and Domestic Politics: The Logic of Two-Level Games', International Organization 42:3, 427-60.

Puntscher Riekmann, S. and Wydra, D. (2013) 'Representation in the European State of Emergency: Parliaments against Governments?' Journal of European Integration, $35: 5,565-582$.

Raunio, T. (2005) 'Hesitant Voters, Committed Elite: Explaining the Lack of Eurosceptic Parties in Finland', Journal of European Integration, 27:4, 381-395. 
Reif, K.-H. and Schmitt, H. (1980) 'Nine second-order national elections - a conceptual framework for the analysis of European election results', European Journal of Political Research, 8:1, 3-44.

Risse, T. (2005) 'Neofunctionalism, European Identity and the Puzzles of European Integration', Journal of European Public Policy, 12:2, 291-309.

Rittberger, Berthold (2005) Building Europe's Parliament. Democratic Representation Beyond the Nation State, (Oxford: Oxford University Press)

Rodrik, D. (2011) The Globalization Paradox Democracy and the Future of the World Economy (New York and London: W.W. Norton \& Company).

Savage, Deborah and Weale, Albert (2009) 'Political Representation and the Normative Logic of Two-Level Games', European Political Science Review, 1.1: 6381

Scharpf, F. (2009) 'Legitimacy in the Multilevel European Polity', European Political Science Review, 1:1, 173-204.

Scharpf, F. (2015) 'After the Crash: A Perspective on Multilevel European Democracy’, European Law Journal, 21:3, 384-405.

Schmidt, V. A. (2006) Democracy in Europe: The EU and National Polities (Oxford: Oxford University Press).

Stilz, A. (2009) Liberal Loyalty: Freedom, Obligation and the State (Princeton, NJ: Princeton University Press).

Thomassen, J. and Schmitt, H. (1997) 'Policy Representation', European Journal of Political Research, 32:2, 165-184.

Vilpisauskas 2013

de Vries, C. (2007) 'Sleeping Giant: Fact or Fairytale? How European Integration Affects National Elections', European Union Politics, 8:3, 363-385.

Wendler, F. (2012) 'Debating the European Debt Crisis: Government leadership, party ideology and supranational integration as focal points of parliamentary debates in Austria, Germany and the United Kingdom', Washington, D.C., American Consortium on European Union Studies (ACES), ACES Cases, No. 2012.3.

Wendler, F. (2014a) 'Justification and political polarization in national parliamentary debates on EU treaty reform', Journal of European Public Policy, 21:4, 549-567.

Wendler, F. (2014b) Debating the Eurozone Crisis in National Parliaments: Contesting the Utility, Principles, and Legitimacy of Crisis Management Paper prepared for the Research conference: "Crisis Contained, Democracy Diminished? The Politics of the Eurozone Crisis", Carleton University, Ottawa, 19-20 September 2014. 
de Wilde, P. and Zürn, M. (2012) 'Can the politicization of European integration be reversed?' Journal of Common Market Studies, 50:1, 139-153.

Winzen, T. (2012) 'National parliamentary control of European Union affairs: a crossnational and longitudinal comparison', West European Politics, 35:3, 657-72.

Winzen, T. (2013) 'European integration and national parliamentary oversight institution', European Union Politics, 14, 297-323.

Winzen, T. et al. (2014) 'Parliamentary co-evolution: national parliamentary reactions to the empowerment of the European Parliament', Journal of European Public Policy, DOI: $10.1080 / 13501763.2014 .881415$

\footnotetext{
${ }^{1}$ We are grateful to the Hanse-Wissenschaftskolleg in Delmenhorst for supporting the research for this paper. Richard Bellamy also acknowledges the support of the Leverhulme Trust for a Research Fellowship RF-2012-368. We would alse-like to thank the anonymous reviewer, Ben Crum and Cristina Fasone for providing very eonstructive-supportive and helpful written comments, as well as the participants of seminars in Delmenhorst, Ottawa, Zürich, Cardiff and Rome for their constructive discussions of earlier versions of this paper.
}

${ }^{2}$ Although Schimmelfennig 2014 suggests that neo-functionalists could claim that there has been some supranational institution building in response to the crisis, such as the Fiscal Compact, it is noticeable that such initiatives have had to largely operate outside the established democratic framework of the EU and only been possible when supported by governments that have been more pro-EU than their populations, and as in Ireland, Italy and Greece, thereby risked rejection by voters once an election occurred. Nevertheless, dissent from the handling of the crisis has not meant that most citizens want to leave the Euro let alone the EU, merely that their support has become more critical (Hobolt and Wratil 2015; Braun and Tausendpfund 2014). 